\title{
Diversity of larger consumers enhances interference competition effects on smaller competitors
}

\author{
Francisco J. A. Nascimento • Agnes M. L. Karlson • \\ Johan Näslund • Ragnar Elmgren
}

Received: 25 November 2009/ Accepted: 22 November 2010/Published online: 16 December 2010

(C) The Author(s) 2010. This article is published with open access at Springerlink.com

\begin{abstract}
Competition between large and small species for the same food is common in a number of ecosystems including aquatic ones. How diversity of larger consumers affects the access of smaller competitors to a limiting resource is not well understood. We tested experimentally how species richness ( $0-3$ spp.) of benthic deposit-feeding macrofauna changes meiofaunal ostracods' incorporation of fresh organic matter from a stable-isotope-labeled cyanobacterial bloom, using fauna from the species-poor Baltic Sea. Presence of macrofauna mostly decreased meiofaunal incorporation of bloom material, depending on the macrofauna species present. As expected, the species identity of macrofauna influenced the incorporation of organic matter by meiofauna. Interestingly, our results show that, in addition, species richness of the macrofauna significantly reduced meiofauna incorporation of freshly settled nitrogen and carbon. With more than one macrofauna species, the reduction was always greater than expected from the single-species treatments. Field data from the Baltic Sea showed a negative correlation between macrofauna diversity and meiofaunal ostracod abundance,
\end{abstract}

Communicated by Craig Osenberg.

F. J. A. Nascimento ( $\square)$ · A. M. L. Karlson ·

J. Näslund $\cdot$ R. Elmgren

Department of Systems Ecology,

Stockholm University, 10691 Stockholm,

Sweden

e-mail: francisco@ecology.su.se

A. M. L. Karlson

e-mail: agnes@ecology.su.se

J. Näslund

e-mail: johan@ecology.su.se

R. Elmgren

e-mail: ragnar.elmgren@ecology.su.se as expected from the experimental results. We argue that this is caused by interference competition, due to spatial niche differentiation between macrofauna species reducing the sediment volume in which ostracods can feed undisturbed by larger competitors. Interference from macrofauna significantly reduces organic matter incorporation by meiofauna, indicating that diversity of larger consumers is an important factor controlling the access of smaller competitors to a limiting food resource.

Keywords Asymmetrical competition . Biodiversity · Complementarity · Resource partitioning $\cdot$ Species richness

\section{Introduction}

Understanding how many species can coexist on a few limiting resources has long been a central issue in ecology. Interspecific competition is a primary ecological mechanism influencing the abundance, distribution and coexistence of species, and hence the diversity of ecological communities (Chase et al. 2002; Connell 1983; Schoener 1983). Competition between species can occur through exploitative competition, where negative interactions arise from the removal of a shared resource, or through interference competition, where foragers reduce the capacity of other species to utilize this resource through behavioral mechanisms (Amarasekare 2002; Begon et al. 1990). Although potentially as important as exploitative competition, interference competition is less well understood (Adler and Mosquera 2000; Valeix et al. 2007).

Body size is a trait that commonly differentiates coexisting species, often with important consequences for ecological relationships (Basset and Angelis 2007; De 
Roos et al. 2003). Larger animals tend to benefit from their size, which increases interference cost for smaller species, thus creating asymmetrical competition (Persson 1985), which may result in reduced access to resources and switching to alternative resources by the smaller species (Amarasekare 2003). As a result, interference competition by larger species can play an important role in structuring ecological communities (Lawton and Hassell 1981; Persson 1985). Although some studies have focused on the role of interference by large species in consumer-resource relationship (Basset and Angelis 2007; Valeix et al. 2007), to our knowledge, none have looked at how their species richness influences the intensity of interference competition with smaller species.

Body size-regulated interference competition is probably an important mechanism shaping soft sediment bottom ecosystems, one of the most extensive habitats on Earth (Aljetlawi and Leonardsson 2002; Wilson 1990). Metazoan assemblages in soft sediment bottoms often show a strong dichotomy in size, and have traditionally been divided into macro- and meiofauna, with organisms retained on 0.5 - or 1-mm mesh classified as macrofauna, and those passing through this mesh, but retained on a $40-\mu \mathrm{m}$ mesh, as meiofauna (Giere 2009). Since most soft-bottom sediments are situated below the photic zone, benthic assemblages are often critically dependent on the supply of organic matter from settling phytoplankton blooms (Graf 1992). How interspecific competition regulates the use of this resource by benthic deposit-feeding species is important for understanding their coexistence (Byrén et al. 2006).

The activities of animals in the sediment, such as bioturbation, can dramatically alter the habitat structure and resource availability of soft-bottom communities (Erwin 2008; Meysman et al. 2006). The size of macrofaunal species give them a greater capacity for bioturbation, and thus increase their potential to physically modulate trophic interactions with meiofauna (Tita et al. 2000), shape their habitat structure (Austen et al. 1998) alter their supply of oxygen (Meyers et al. 1987) and interfere with their access to fresh organic matter from settling phytoplankton blooms (Modig et al. 2000; Ólafsson et al. 2005). Additionally, macrofaunal assemblages are generally composed of species that differ in size, feeding and burrowing activity, mobility, and therefore in bioturbation activity. When macrofaunal species differ in their bioturbation activity, there is a potential for macrofaunal species richness to affect the intensity of interference competition on meiofaunal assemblages (Austen et al. 1998). Therefore, softbottom sediment assemblages are of particular interest for studies of the relationship between species richness and interference competition.

Our study was performed with Baltic Sea soft sediment communities, which due to the Baltic Sea's low salinity and young age have a naturally low biodiversity (Elmgren and Hill 1997). The indigenous deposit-feeding macrofaunal community in much of the Baltic sediments below the photic zone is dominated by only three species. This naturally species-poor ecosystem provides an ideal platform for testing experimentally how interference competition by macrofauna influences meiofaunal feeding on a limiting resource, using realistic and ecologically relevant abundances and combinations of species.

We manipulated macrofaunal species richness and composition by testing all ecologically realistic combinations of the three main indigenous depositing-feeding macrofaunal species in the Baltic Sea, as well as a treatment without macrofauna. After experimental labeling of a typical Baltic Sea summer cyanobacterial bloom with stable isotopes of both carbon and nitrogen (Larsson et al. 2001), we measured incorporation of $\mathrm{N}$ and $\mathrm{C}$ of cyanobacterial origin by the three dominant species of ostracods, the most important meiofaunal group in terms of biomass in the Baltic Sea (Elmgren et al. 1984). We show that the presence of macrofauna greatly reduced the incorporation of fresh organic matter by all three ostracod species, and that this effect was most pronounced at the highest macrofaunal species richness tested (biomass kept constant), indicating that diversity of larger consumers can be an important factor controlling the access of smaller competitors to a limiting resource.

\section{Materials and methods}

\section{Experimental design}

To test how macrofaunal species richness and composition affect incorporation of $\mathrm{N}$ and $\mathrm{C}$ from a freshly settled phytoplankton bloom by meiofauna, we performed an experiment using the three macrofaunal species that dominate the indigenous deposit-feeding macrofauna guild in Baltic Sea sediments: the bivalve Macoma balthica, and the two amphipods Monoporeia affinis and Pontoporeia femorata. These macrofauna species differ in their feeding and bioturbation activities and therefore have the potential to interfere differently with how meiofaunal assemblages process fresh phytodetritus. Macoma balthica is semimobile, burrowing surface feeder, that uses its siphon to forage on the surface sediment (Ólafsson et al. 2005), while both amphipods are mobile bioturbators, with $M$. affinis predominantly a surface feeder and $P$. femorata a subsurface feeder (Byrén et al. 2006; Lopez and Elmgren 1989). Meiofaunal communities in the Baltic Sea proper are generally dominated in biomass by three ostracod species: Candona neglecta, Paracyprideis fennica and Heterocyprideis sorbyana (Elmgren et al. 1984). Two different 
feeding ecologies are found among these species, with C. neglecta feeding preferentially on freshly deposited detritus while $P$. fennica and $H$. sorbyana rely more on older organic matter (Nascimento et al. 2008; Ólafsson et al. 1999). As these three ostracod species do not seem to compete strongly for freshly settled phytodetritus (Modig et al. 2000) and, since sorting live meiofaunal animals is extremely time consuming, we used natural abundances of $C$. neglecta, $P$. fennica and $H$. sorbyana in the experiment (C. neglecta: $1.5 \pm 0.3$ ind. $10 \mathrm{~cm}^{-2}$; $P$. fennica: $11 \pm 1$ ind. $10 \mathrm{~cm}^{-2} ;$ H. sorbyana: $7 \pm 0.9$ ind $10 \mathrm{~cm}^{-2} ; n=3$, mean \pm standard deviation, $S D$ ).

Our experiment included seven treatments, each with eight replicates, using a substitutive design, where macrofaunal species richness varied $(0,1,2$ or 3$)$ while density and biomass of animals was kept as constant as possible. Our experimental design included: (1) a treatment without macrofauna (NoMac), (2) three macrofauna monoculture treatments with 24 ind. per replicate, one for each depositfeeding macrofaunal species $M$. affinis (Ma), P. femorata (Pf), and M. balthica (Mb), (3) a treatment containing a mixture of all three macrofaunal species together $(\mathrm{Ma}+$ $\mathrm{Pf}+\mathrm{Mb}$ ), with 8 ind. of each of the three macrofaunal species per replicate, and (4) two treatments with two macrofaunal species $(\mathrm{Ma}+\mathrm{Pf}$, and $\mathrm{Ma}+\mathrm{Mb})$ with 12 ind. of each species per replicate. We did not include a P. femorata plus $M$. balthica treatment since this community composition is rarely found in nature. This design allows the identification of potential interference competition effects on meiofaunal incorporation of fresh organic matter due to macrofaunal species composition and richness.

\section{Phytoplankton collection and labeling}

A cyanobacterial bloom dominated by Nodularia spumigena was collected at $1-1.5 \mathrm{~m}$ depth in the open Baltic proper on 6 July 2006, using a $100-\mu \mathrm{m}$ plankton net. The cyanobacteria were separated from mesozooplankton using a light trap, as described in Nascimento et al. (2009). After zooplankton removal, the cyanobacterial suspension was incubated for 7 days in the laboratory under constant shaking and illumination at $19^{\circ} \mathrm{C}$ in $\mathrm{f} / 2$ medium, where the inorganic $\mathrm{C}$ and $\mathrm{N}$ sources were entirely composed of $\mathrm{NaH}^{13} \mathrm{CO}_{3}$ and ${ }^{15} \mathrm{NH}_{4} \mathrm{Cl}$ (Cambridge isotopes, 99\% heavy isotope), respectively. The ${ }^{13} \mathrm{C}$ - and ${ }^{15} \mathrm{~N}$-labelled cyanobacteria were then harvested by creating a sharp pressure shock to break their gas vacuoles (Walsby 1975), causing them to settle to the bottom, after which they were sieved through a $27-\mu \mathrm{m}$ sieve and rinsed with filtered brackish seawater to remove non-incorporated ${ }^{13} \mathrm{C}$ and ${ }^{15} \mathrm{~N}$. The harvested cyanobacteria were concentrated to a dense stock suspension and samples of this suspension were taken for stable isotope analysis (SIA).
Sediment sampling

Surface sediment was collected in May 2006 from a depth of $27 \mathrm{~m}$ in the northern Baltic proper $\left(58^{\circ} 49^{\prime} \mathrm{N}, 17^{\circ} 31^{\prime} \mathrm{E}\right)$ using an epibenthic sled (Blomqvist and Lundgren 1996) set to a depth of $3 \mathrm{~cm}$. The sediment in this area is characterized as silty clay with high water content $(87 \%$ in the top centimetre) and a $\mathrm{C} / \mathrm{N}$ ratio of $7.6 \pm 0.1(n=3)$. The sediment was sieved through a $1-\mathrm{mm}$ sieve to remove the macrofauna while retaining the natural abundance of meiofaunal ostracods. After homogenization, $500 \mathrm{~cm}^{3}$ of the sieved sediment were carefully transferred to each of 56 Plexiglas microcosms (surface area $50 \mathrm{~cm}^{2}$ ), followed by the addition of $450 \mathrm{~mL}$ of brackish seawater $(6$ psu) pumped in from a depth of $15 \mathrm{~m}$ near where the sediment was collected, and filtered through a sand filter and a $40-\mu \mathrm{m}$ sieve.

The sediment was left to settle for 1 day, after which each microcosm was supplied with gentle aeration to avoid anoxic conditions, and left to equilibrate for 4 weeks in the dark at $5 \pm 1 \mathrm{C}$, a temperature similar to that in the field at that depth at this time of year. Before the start of the experiment, individuals of $M$. affinis, $P$. femorata and $M$. balthica were collected from the same location as the sediment using the epibenthic sled, separated using a 1-mm mesh sieve, and stored in the dark in sediment at $5 \pm 1{ }^{\circ} \mathrm{C}$ with aeration until the start of the experiment.

Addition of macrofauna and simulation of the settling of the cyanobacterial bloom

Active individuals of M. affinis, P. femorata and M. balthica of similar shell-free dry mass (M. affinis: $1.9 \pm 0.4$; P. femorata: $1.8 \pm 0.2 ; \quad M$. balthica: $2.1 \pm 0.8 \mathrm{mg}$; $n=30$, mean \pm standard deviation, $\mathrm{SD}$ ) were added to the experimental microcosms, to achieve a total density of 24 individual per replicate or 4,800 ind. $\mathrm{m}^{-2}$ which is within the range of abundances usually found in the field (Ankar and Elmgren 1976). Five days after the addition of macrofauna, the experiment was started by adding approximately $16 \mathrm{ml}$ of the harvested cyanobacterial liquid suspension, corresponding to $156 \pm 16 \mathrm{mg}$ dry mass (mean $\pm \mathrm{SD}$ ) or $13.7 \mathrm{~g} \mathrm{C} \mathrm{m}^{-2}$ to the water column of each microcosm. This is equivalent to about 1 month of sedimentation of phytoplankton material during a summer bloom in the area (Heiskanen et al. 1998). The experimental incubation ran for 4 weeks in the dark at $5^{\circ} \mathrm{C}$.

Termination of the experiment

Sediment samples were taken from all replicates with cutoff syringes $(\varnothing 1.5 \mathrm{~cm})$, which were immediately frozen at $-20^{\circ} \mathrm{C}$ and later sliced in $0.5-\mathrm{cm}$ layers down to $5 \mathrm{~cm}$ 
depth. Each layer was homogenized, weighed before and after drying at $60^{\circ} \mathrm{C}$ and sub sampled (15 mg dry mass) for SIA. We did not sample below the top $5 \mathrm{~cm}$ of sediment because the amounts of label there are expected to be negligible since no macrofauna and very little meiofauna live in sediments below $5 \mathrm{~cm}$. Without bioturbation, the transport of label to this dephs would be insignificant in the timescale of this experiment.

After the sampling with the cut-off syringes, the remaining surface sediment layer $(0-1 \mathrm{~cm})$ where $95 \%$ of Baltic ostracods normally are found (Ólafsson et al. 1999) in each microcosm was sliced off and sieved sequentially through 1,000- and 40- $\mu \mathrm{m}$ sieves, and the contents of the $40-\mu \mathrm{m}$ sieve preserved in $4 \%$ formalin. The macrofauna retained in the $1,000-\mu \mathrm{m}$ sieve were put in filtered sea water for $24 \mathrm{~h}$ to empty their gut, rinsed in distilled water, dried at $60^{\circ} \mathrm{C}$, weighed (bivalve without shell) and put in tin capsules for SIA. The differences in macrofaunal isotope values and incorporation of organic matter among treatments are described and discussed in Karlson et al. (2010).

\section{Ostracod extraction from the sediment}

The meiofauna was extracted from the $40-\mu \mathrm{m}$ sediment fraction using Ludox colloidal silica at a specific gravity of 1.15 (Ólafsson et al. 1999). Ostracods were sorted, counted and identified to species level. After three extractions, the remaining sediment was again sieved through a $160-\mu \mathrm{m}$ sieve and checked for ostracods under a $\times 50$ binocular stereomicroscope. Extracted ostracods were rinsed in distilled water, sorted, and identified to species level under a $\times 50$ binocular stereomicroscope. Individuals of three ostracod species, Candona neglecta, Heterocyprideis sorbyana, and Paracyprideis fennica, were picked out into a watch glass containing $1 \mathrm{M} \mathrm{HCl}$ to remove inorganic $\mathrm{C}$. After $24 \mathrm{~h}$ in acid- the ostracods were rinsed in distilled water, placed in tin capsules and dried at $60^{\circ} \mathrm{C}$ for $24 \mathrm{~h}$ in preparation for SIA.

Analyses of elemental content of $\mathrm{C}$ and $\mathrm{N}$ and their stable isotope ratios in samples of cyanobacteria, ostracods, and homogenized sediment were made at the UC Davis Stable Isotope Facility, USA. For P. fennica and $H$. sorbyana, 35-45 individuals per replicate of each species were pooled in order to achieve sufficient biomass for reliable SIA (sample range: $0.193-0.680 \mathrm{mg}$ dry mass). For the less abundant $C$. neglecta, individuals from two replicates sometimes had to be pooled to achieve the biomass needed for SIA (sample range: $0.106-0.283 \mathrm{mg}$ dry mass).

All stable-isotope values are given in the $\delta$ notation where:

$\delta^{15} \mathrm{~N}$ or $\delta^{13} \mathrm{C}(\%)=\left[\left(R_{\text {sample }} / R_{\text {standard }}\right)-1\right] \times 10^{3}$ where $R$ is $\left({ }^{15} \mathrm{~N} /{ }^{14} \mathrm{~N}\right.$ or $\left.{ }^{13} \mathrm{C} /{ }^{12} \mathrm{C}\right)$.

To quantify amounts of cyanobacterial $\mathrm{N}$ and $\mathrm{C}$ incorporated by the three ostracod species and stored in the sediment, a linear 2-source mixing model was used for $\mathrm{N}$ and C separately (Karlson et al. 2010):

$\mathrm{f} 1+\mathrm{f} 2=1 ; \mathrm{f} 1=\left(\delta_{\text {sample }}-\delta_{\text {source } 2}\right) /\left(\delta_{\text {source } 1}-\delta_{\text {source } 2}\right)$

where $\mathrm{f} 1$ is the proportion of new $\mathrm{N}$ or $\mathrm{C}$ (of cyanobacterial origin) in the sample (animal or sediment), $\mathrm{f} 2$ is the proportion of aged $\mathrm{N}$ or $\mathrm{C}$ ( $\mathrm{N}$ and $\mathrm{C}$ sources in the initial sediment), $\delta_{\text {source } 1}$ is the isotope value of the added cyanobacteria and $\delta_{\text {source } 2}$ the isotope value of the experimental sediment. Uncorrected isotope data were used in the mixing model, since species-specific differences in fractionation (Goedkoop et al. 2006) and fat content (Post et al. 2007) were negligible compared to the strong labeling. This model was used to calculate the proportion of $\mathrm{N}$ and $\mathrm{C}$ of cyanobacterial origin in each ostracod sample. This value was then extrapolated to the total biomass of each ostracod species in each replicate, to obtain the total of $\mathrm{N}$ and $\mathrm{C}$ incorporated by the ostracods as a community.

The amount of $\mathrm{N}$ and $\mathrm{C}$ of cyanobacterial origin in the sediment was also calculated from this mixing model, by summing the $\mathrm{N}$ and $\mathrm{C}$ content of all layers (Karlson et al. 2010).

Expected incorporation values $\left(I_{\text {exp }}\right)$ of cyanobacterial $\mathrm{N}$ and $\mathrm{C}$ by the ostracod community in the multi-macrofauna species treatments $(\mathrm{Ma}+\mathrm{Pf}, \mathrm{Ma}+\mathrm{Mb}$ and $\mathrm{Ma}+\mathrm{Pf}+$ $\mathrm{Mb})$ were calculated by subtracting the incorporation by ostracods in each replicate of the macrofauna monocultures $\left(I_{\mathrm{x}}\right)$ from the average incorporation in the treatment without macrofauna $\left(I_{\text {NoMac }}\right)$. This enables the calculation of how much incorporation by ostracods was reduced by the presence of each macrofauna species $(T)$. Assuming that each of the macrofauna individual of the same species causes approximately the same $T$ on ostracod incorporation, it is possible to calculate $T$ per macrofauna individual for each macrofauna species $\left(T \operatorname{ind}_{\mathrm{x}}^{-1}\right)$ by dividing $T$ by the number of macrofauna individuals present in the corresponding replicate of the macrofauna monocultures. Multiplying $\mathrm{T}_{\mathrm{ind}}^{-1}$ by the number of corresponding macrofauna individuals in the mixed treatments, will give the expected $T$ of each macrofauna species within the mixed treatment $\left(T_{\mathrm{x}}\right)$. Then $T$ for the a mixed treatment would be expressed as:

$T_{\text {mixed treatment }}=T_{\text {species a }}+T_{\text {species b }}$

It is then possible to determine expected incorporation in the mixed treatments $\left(I_{\text {exp }}\right)$ by subtracting $T_{\text {mixed treatment }}$ from $I_{\text {NoMac, }}$

$I_{\text {exp }}=I_{\text {NoMac }}-T_{\text {mixed treatment. }}$ 
Net effects of macrofaunal species richness on incorporation of cyanobacterial $\mathrm{C}$ and $\mathrm{N}$ were calculated as the differences between observed and expected incorporation values in multi-macrofaunal species treatments.

\section{Statistics}

The effects of both species richness and species composition on interference were tested in a nested ANOVA. Macrofaunal species composition was set as a factor nested under species richness with interference on ostracod community incorporation of $\mathrm{N}$ or $\mathrm{C}$ as the dependent variable. The differences among treatments in $\mathrm{N}$ or $\mathrm{C}$ content of cyanobacterial origin within and below the first centimetre of sediment at the end of the experiment were tested with one-way ANOVA. Cochran's test was used to check the assumption of homoscedasticity and when necessary the data were log-transformed to obtain homogeneity of variance. Paired a posteriori comparisons were carried out using Tukey HSD. To test if the observed interference on ostracod community incorporation of $\mathrm{N}$ and $\mathrm{C}$ was significantly different from the predicted, a single mean $t$ test was performed for each of the multi-macrofaunal treatments, for both $\mathrm{N}$ and $\mathrm{C}$. Potential differences in survival of macrofaunal species were tested using non-parametric Kruskal-Wallis.

\section{Results}

Cyanobacterial bloom composition and labeling

The cyanobacterium $N$. spumigena made up $97 \%$ of the phytoplankton biovolume, with diatoms Amphora spp. and resting cells of the cyanobacterium Anabaena lemmermannii accounting for the rest. After labeling with $\mathrm{NaH}^{13} \mathrm{CO}_{3}$ and ${ }^{15} \mathrm{NH}_{4} \mathrm{Cl}$, the isotope values (mean $\pm \mathrm{SD}$ ) of the cyanobacterial suspension increased from $-1.4 \pm 0.4$ to $906 \pm$ 32 for $\delta^{15} \mathrm{~N}$ and from $-23.7 \pm 0.2$ to $157 \pm 6$ for $\delta^{13} \mathrm{C}$.
Isotope values of ostracods and sediment before the experiment

Sediment isotope values before the cyanobacterial addition were $5.0 \pm 0.1$ for $\delta^{15} \mathrm{~N}$ and $-22.9 \pm 0.1$ for $\delta^{13} \mathrm{C}$ $(n=3)$, while initial $\delta^{15} \mathrm{~N}$ and the $\delta^{13} \mathrm{C}$ values were $6.5 \pm 0.5$ and $-21.9 \pm 0.2$ for C. neglecta, $8.4 \pm 0.7$, $-21.3 \pm 0.3$ for $P$. fennica, and $8.2 \pm 0.8$ and $-21.8 \pm$ 0.1 for $H$. sorbyana ( $n=3$ in all cases).

Macrofaunal survival and ostracod abundance and biomass at the beginning and end of the experiment

Survival of $M$. balthica was high in all treatments (93 $\pm 2 \%$ ), while the amphipods had lower survival of $65 \pm 7 \%$ for $M$. affinis and $57 \pm 5 \%$ for $P$. femorata, with no significant difference in survival among the treatments for any of the species $[M$. affinis; $\mathrm{H}(3, n=32)=6.547$ $P=0.088 ; P$. femorata $; \mathrm{H}(2, n=23)=2.594 P=$ 0.273 ; M. balthica; $\mathrm{H}(2, n=24)=3.290, P=0.193]$. The observed amphipod mortality reflects their higher sensitivity to handling and oxygen stress and is within the range for summertime experiments of similar duration (Bianchi et al. 2000). Final macrofaunal biomass (total biomass of all surviving individuals) was similar among treatments except that the Pf treatment had slightly lower community biomass than the the $\mathrm{Ma}+\mathrm{Pf}+\mathrm{Mb}$ treatment $\left(F_{5,41}=3.03, P=0.007\right)$ (see Table 1$)$.

The abundance and biomass of ostracods before the beginning of the experiment were $94 \pm 7$ ind. $50 \mathrm{~cm}^{-2}$ and $1.25 \pm 0.2 \mathrm{mg} \mathrm{dw}^{-1}$, respectively. The values for ostracod abundance and biomass at the end of the experiment are presented in Table 1 . There were no significant differences among treatments in ostracod abundance at the end of the experiment or between the initial abundance of ostracods and the abundance in all the other treatments at the end of the experience (ANOVA, $F_{6,23}=1.2, P=0.4$ for $C$. neglecta; $F_{6,31}=1.8, P=0.1$ for $P$. fennica; $F_{6,31}=0.4, P=0.8$ for $H$. sorbyana). There were no significant differences in biomass among the treatments at
Table 1 Abundance and biomass of the macrofauna and ostracods in the different treatments

Values represent average $\pm \mathrm{SE}$

\begin{tabular}{llc}
\hline Treatment & $\begin{array}{l}\text { Macrofaunal final abundance } \\
\left.\text { (ind. } 50 \mathrm{~cm}^{-2}\right) / \text { biomass }\left(\mathrm{g} \mathrm{dw}^{-1}\right)\end{array}$ & $\begin{array}{l}\text { Ostracod final abundance } \\
\left.\text { (ind. } 50 \mathrm{~cm}^{-2}\right) / \text { biomass }\left(\mathrm{mg} \mathrm{dw}^{-1}\right)\end{array}$ \\
\hline $\mathrm{NoMac}$ & - & $97 \pm 9 / 0.85 \pm 0.2$ \\
$\mathrm{Ma}$ & $14 \pm 0.8 / 28 \pm 2$ & $81 \pm 7 / 1.0 \pm 0.1$ \\
$\mathrm{Pf}$ & $13 \pm 0.2 / 26 \pm 1$ & $96 \pm 7 / 1.3 \pm 0.2$ \\
$\mathrm{Mb}$ & $21 \pm 0.5 / 32 \pm 0.6$ & $89 \pm 8 / 1.1 \pm 0.2$ \\
$\mathrm{Ma}+\mathrm{Pf}$ & $15 \pm 0.4 / 32 \pm 0.7$ & $107 \pm 8 / 1.3 \pm 0.1$ \\
$\mathrm{Ma}+\mathrm{Mb}$ & $18 \pm 0.9 / 32 \pm 1$ & $94 \pm 8 / 1.8 \pm 0.3$ \\
$\mathrm{Ma}+\mathrm{Pf}+\mathrm{Mb}$ & $17 \pm 0.7 / 30 \pm 1$ & $100 \pm 7 / 1.3 \pm 0.1$ \\
\hline
\end{tabular}


the end of the experiment or between initial biomass of ostracods and all the other treatments at the end of the experiment (ANOVA, $F_{1,6}=2.3, P=0.07$ for $C$. $n e g$ lecta; $F_{1,6}=0.8, P=0.59$ for $P$. fennica; $F_{1,6}=1.9$, $P=0.2$ for $H$. sorbyana). Furthermore, no significant differences were found in initial $\mathrm{N}$ or $\mathrm{C}$ content for any of the ostracods (data not shown).

Ostracod isotope values after the experiment

The ostracod isotope values at the end of the experiment showed that all three species had incorporated cyanobacterial $\mathrm{N}$ and $\mathrm{C}$, with significant differences among treatments (Fig. 1). Ostracod stable $\mathrm{N}$ isotope values often decreased markedly, indicating decreased incorporation of cyanobacterial $\mathrm{N}$, when a macrofaunal species was present in the experimental sediments, but this depended greatly on identity of the species (nested ANOVA, composition: $F_{3,23}=9.34, P=0.0003$ for $C$. neglecta $; F_{3,42}=16.7$, $P<0.00001$ for $P$. fennica; $F_{3,42}=8.6, P=0.0001$ for H. sorbyana). In addition, increased macrofaunal species richness significantly decreased the nitrogen isotope values for all ostracod species, again indicating lower incorporation of cyanobacterial $\mathrm{N}\left(F_{3,23}=21.1, P<0.00001\right.$, for C. neglecta; $F_{3,42}=23.0, P<0.00001$ for $P$. fennica; $F_{3,42}=27.6, P<0.00001$ for $H$. sorbyana). Similar decreases were found for carbon isotope values, but while macrofaunal species richness significantly lowered the carbon isotope values (nested ANOVA, $F_{3,23}=0.21$, $P=0.0001$ for $C$. neglecta; $F_{3,42}=36.4, P<0.00001$ for P. fennica; $F_{3,42}=16.3, P<0.00001$ for $H$. sorbyana), the effect of species composition on $\delta^{13} \mathrm{C}$ values was significant only for $P$. fennica (nested ANOVA, $F_{3,42}=21.3$, $P<0.00001$ ).

Candona neglecta had the highest $\mathrm{N}$ and $\mathrm{C}$ isotope values in the absence of macrofauna, indicating a more rapid incorporation of freshly deposited $\mathrm{N}$ and $\mathrm{C}$ (Fig. 1a), but also showed the greatest reduction in incorporation when together with macrofauna. A similar but lower decrease in incorporation of $\mathrm{N}$ and $\mathrm{C}$ of cyanobacterial origin in the presence of macrofauna was seen for $P$. fennica and $H$. sorbyana (Fig. $1 \mathrm{~b}$ and $\mathrm{c}$, respectively), which are naturally less dependent on fresh organic matter.

Ostracod community incorporation of cyanobacterial $\mathrm{N}$ and $\mathrm{C}$

There were marked differences among treatments in the degree to which macrofauna reduced the ostracod community's incorporation of cyanobacterial $\mathrm{N}$ and $\mathrm{C}$ (uncrossed bars in Fig. 3a for $\mathrm{N}$ and Fig. 3b for C). Macrofaunal species composition significantly affected the incorporation of cyanobacterial $\mathrm{N}$ and $\mathrm{C}$ by ostracod
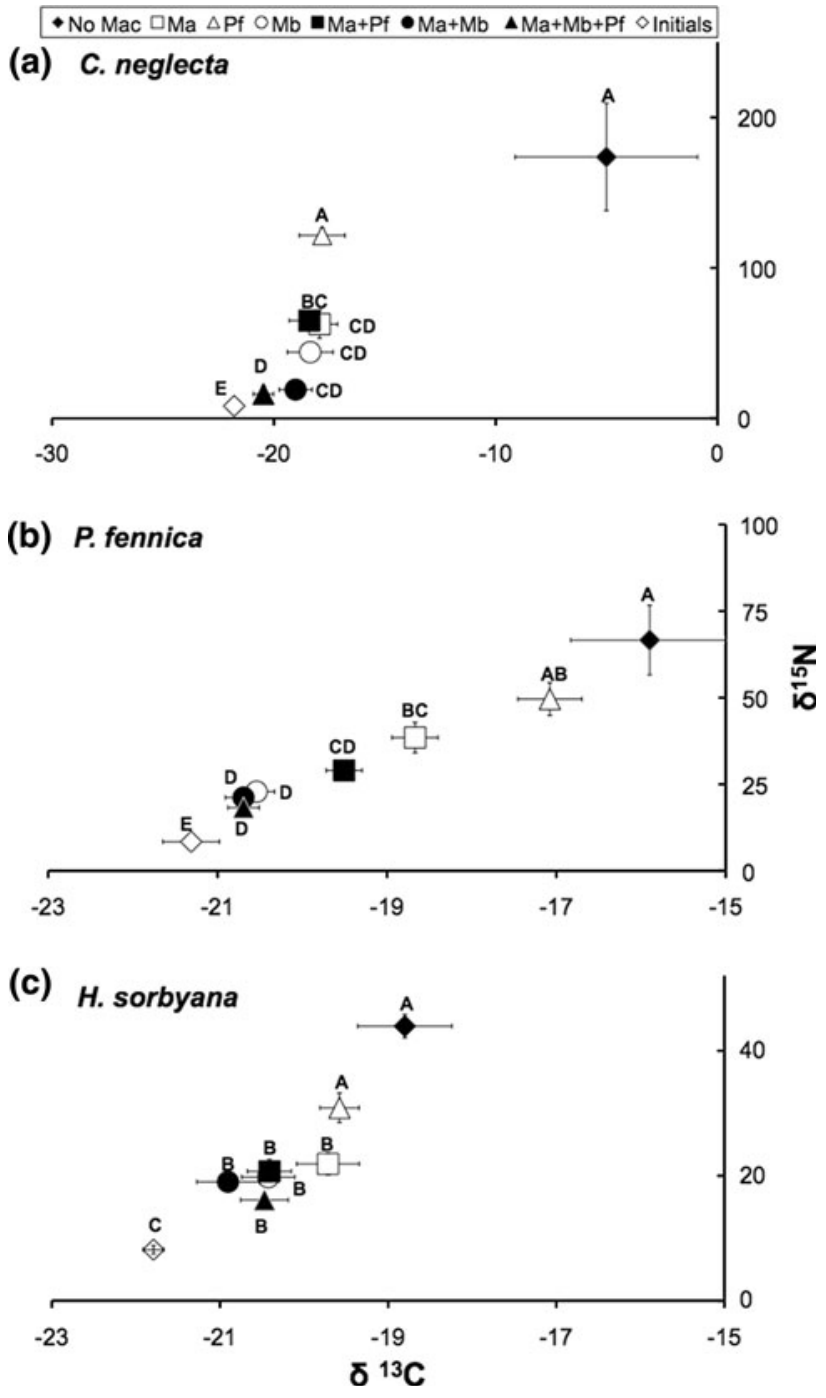

Fig. 1 Isotope values $( \pm$ SE) for a $C$. neglecta $(n=5)$; b $P$. fennica $(n=7)$; c H. sorbyana $(n=7)$ in treatments with different combinations of macrofauna species. NoMac no macrofauna; Ma M. affinis alone; Pf P. femorata alone; $M b$ M. balthica alone; $M a+P f$ M. affinis $+P$. femorata; $M a+M b M$. affinis $+M$. balthica; $M a+P f+M b$ all three macrofauna species; Initial natural isotope values before experiment. Different letters indicate significant differences (nested ANOVA) in nitrogen isotope values among treatments for the three species $(P<0.05)$. Statistical differences in carbon isotope values followed the same pattern but are not shown here (see text for statistical details)

assemblages (nested ANOVA, $F_{3,34}=33.7, P<0.00001$ for $\mathrm{N} ; F_{3,34}=11.9, P<0.0001$ for $\mathrm{C}$ ), and increased macrofauna species richness significantly reduced the amounts of labelled $\mathrm{N}$ and $\mathrm{C}$ incorporated by the ostracod community (nested ANOVA, $F_{3,34}=96.6, P<0.00001$ for $\mathrm{N} ; F_{3,34}=71.8, P<0.00001$ for $\mathrm{C}$ ). Importantly, our results show significantly reduced incorporation of both $\mathrm{N}$ and $\mathrm{C}$ in all treatments with macrofaunal species, with observed incorporation values (crossed bars in Fig. 2) always being lower than expected in the treatments with 

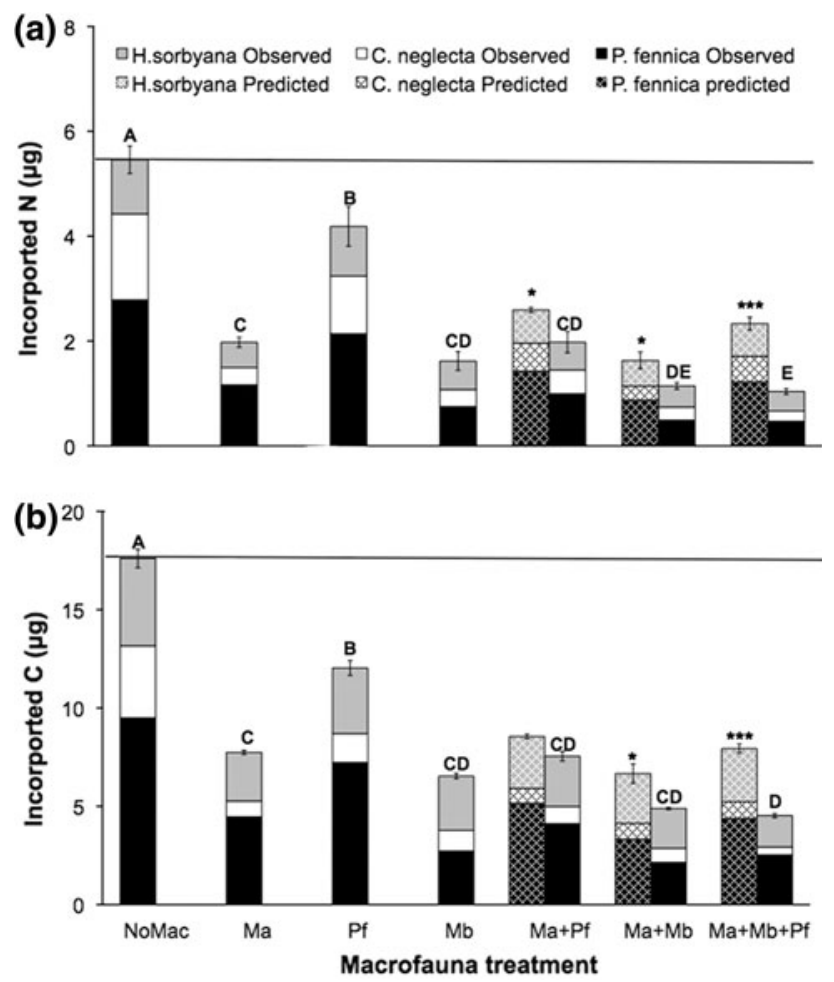

Fig. 2 Ostracod community incorporation of freshly deposited a $\mathrm{N}$ and $\mathbf{b} \mathbf{C}$ in the different macrofauna treatments, with observed contribution from each ostracod species shown (P. fennica, black; C. neglecta, white; and H. sorbyana, grey). Ma M. affinis alone; Pf P. femorata alone; $M b$ M. balthica alone; $M a+P f M$. affinis $+P$. femorata $M a+M b M$. affinis $+M$. balthica $M a+P f+M b$ all three macrofauna species. Distance to the horizontal line represents the reduction in incorporation of $\mathrm{N}$ and $\mathrm{C}$ by ostracods when one or more macrofauna species are present. Different letters indicate significant differences (nested ANOVA) among treatments in ostracod community incorporation of $\mathrm{N}$ and $\mathrm{C}$. For multi-macrofaunal species treatments the expected values based on additive monoculture performance, corrected for macrofauna mortality, are shown (crossed bars; P. fennica -black; C. neglecta- white and H. sorbyana-grey). Asterisks represent significant differences between expected and observed incorporation ( $t$ test: $* P<0.05$; $* * * P<0.0001)$. Values are mean $\pm \operatorname{SE}(n=6)$

more than one macrofaunal species (see Fig. 2a, b for $P$ values), and the greatest reduction found where all three macrofauna species were present.

\section{Sediment content of cyanobacterial $\mathrm{N}$ and $\mathrm{C}$} after the experiment

There were no significant differences among treatments in content of labelled $\mathrm{N}$ or $\mathrm{C}$ in the upper centimetre of sediment (Fig. 3a, b), where ostracods and most other meiofaunal groups live (ANOVA, $F_{6,48}=0.9, P=0.49$ for $\mathrm{N} ; F_{6,48}=0.7, P=0.69$, for $\mathrm{C}$ ). We were not able to account for all the label added to our experimental system. It is reasonable to assume that part was lost to the atmosphere as respired $\mathrm{CO}_{2}$ or as $\mathrm{NH}_{4}$. In addition, due to the
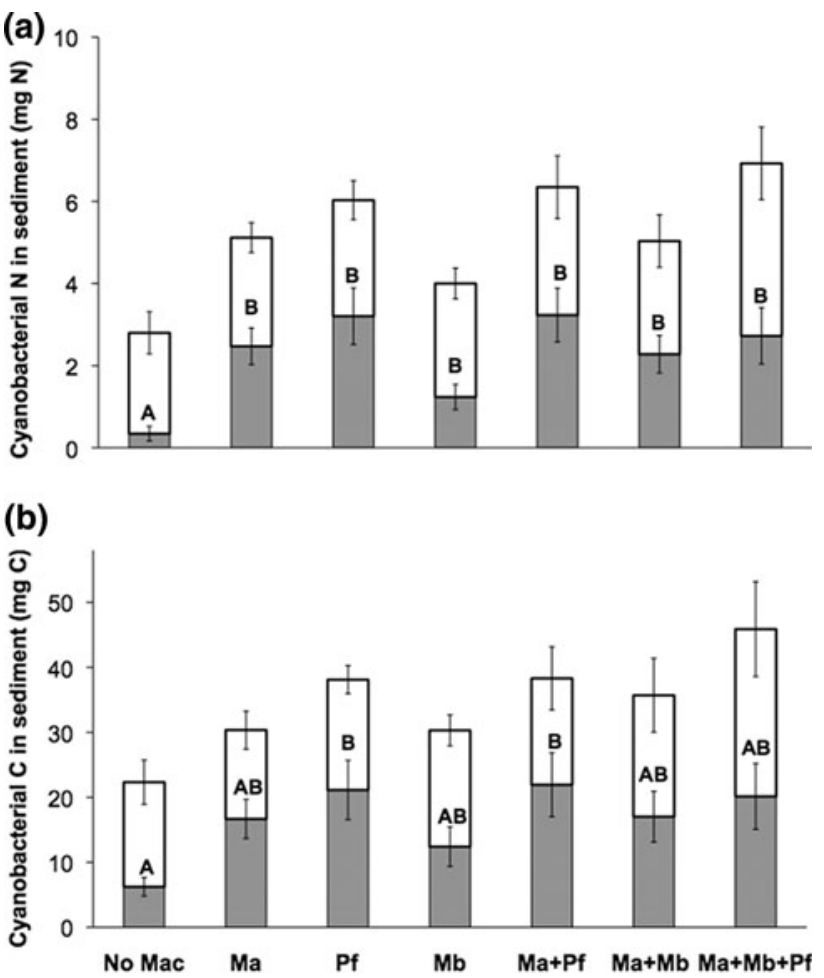

Fig. 3 Sediment content of cyanobacterial a nitrogen and $\mathbf{b}$ carbon above (open bars) and below (filled bars) the first centimeter of sediment at the end of the experiment. NoMac no macrofauna; Ma M. affinis alone; Pf P. femorata alone; $M b$ M. balthica alone; $M a+P f$ $M$. affinis $+P$. femorata; $M a+M b$ M. affinis $+M$. balthica; $M a+P f+M b$ all three macrofauna species. Values are mean $\pm \mathrm{SE}$ $(n=8)$, different letters indicate significant differences (ANOVA) below the first centimeter of sediment. In the first centimeter, where most of the ostracods are found, there were no significant differences in $\mathrm{N}$ or $\mathrm{C}$ content

burrows in the sediment created by the infauna, one can expect the concentration label in the sediment to be patchy and thus hard to sample difficult to subsample accurately.

\section{Discussion}

We found that the incorporation of fresh organic matter by ostracods was influenced both by the species of macrofauna, and by the number of macrofauna species present in the treatment (Fig. 1).

Regarding the effects of the macrofaunal species composition, even though $P$. femorata itself incorporated large amounts of fresh organic matter (Karlson et al. 2010) the isotope values of the three ostracod species in the treatment with $P$. femorata alone show that it did not significantly alter incorporation by any of the three ostracod species. This is probably due to the activity of $P$. femorata being mainly below the surface, away from the first centimetre of sediment where ostracods live and feed. The effects of the surface-feeding $M$. affinis tested alone were intermediate, 
while $M$. balthica tested singly reduced incorporation by all three ostracod species to a greater extent than any of the amphipods. Even though this bivalve is the least mobile of the tested macrofauna species, it uses its long siphon to forage through surface sediment for phytodetritus several times a day (Ólafsson et al. 2005). The overall activity of $M$. balthica, with both the siphon and the bivalve itself moving about in the sediment, clearly result in a disturbance that interferes greatly with ostracod access to food freshly deposited on the sediment surface.

Incorporation of cyanobacterial $\mathrm{N}$ and $\mathrm{C}$ by all three ostracods was clearly reduced in treatments with macrofauna, indicating reduced feeding on freshly deposited cyanobacteria. Incorporation of label was lowest for all the three ostracod species in the $\mathrm{Ma}+\mathrm{Pf}+\mathrm{Mb}$ treatment (Fig. 1), even though there was no significant difference in the surface sediment content of cyanobacterial $\mathrm{N}$ and $\mathrm{C}$ among treatments at the end of the experiment (Fig. 3). Furthermore, there was no significant difference between the treatments with macrofauna in the amounts of cyanobacterial $\mathrm{N}$ and $\mathrm{C}$ buried beneath the top centimeter of the sediment. This indicates that the lower incorporation of cyanobacterial $\mathrm{N}$ and $\mathrm{C}$ by meiofauna was not due to burial of phytodetritus by macrofauna. In addition, the low incorporation values for ostracods in the $M$. balthica monoculture, the macrofauna species with lowest incorporation values, also indicate that interference rather than exploitative competition by macrofauna for freshly deposited detritus was the main mechanism behind the differences among the treatments in incorporation of $\mathrm{N}$ and $\mathrm{C}$ by the ostracods. This is further supported by the weak correlations between incorporation of freshly deposited $\mathrm{N}$ and $\mathrm{C}$ by ostracods and macrofauna (data from Karlson et al. 2010) $\left(r^{2}=0.02, P=0.4\right.$ for $\mathrm{N}$; $r^{2}=0.009, P=0.89$ for $\mathrm{C}$ ) and between meiofauna incorporation and surface sediment content of cyanobacterial $\mathrm{N}$ and $\mathrm{C}\left(r^{2}=0.03, P=0.3\right.$ for $\mathrm{N} ; r^{2}=0.06$, $P=0.6$ for $\mathrm{C})$.

Our results show that the reduction in incorporation of labeled $\mathrm{N}$ and $\mathrm{C}$ increased with macrofaunal species richness. In treatments with more than one macrofauna species, the reduction in incorporation of cyanobacterial $\mathrm{N}$ and $\mathrm{C}$ by ostracods was consistently significantly greater (Fig. 2) than expected from the effects of macrofauna species tested singly. This increased interference with higher macrofaunal species richness may be a result of the different feeding and bioturbation activities of the three macrofaunal species hindering ostracod feeding on freshly deposited $\mathrm{N}$ and $\mathrm{C}$ in complementary ways. Several studies have found spatial niche segregation between the two studied amphipods when in sympatry (Byrén et al. 2006; Hill and Elmgren 1987). This increased macrofaunal spatial segregation with higher diversity probably reduces the sediment volume in which meiofauna can avoid the disturbance caused by macrofaunal activity. That the highest interference was found in the $\mathrm{Ma}+\mathrm{Pf}+\mathrm{Mb}$ treatment was possibly due to the sediment reworking activities of $M$. balthica increasing the physical disruption of the sediment caused by the bioturbation of the mobile amphipod M. affinis. A way for ostracods to avoid this surface disturbance would be to move deeper in the sediment. Indeed, Modig et al. (2000) suggested that fine scale stratification within the first $2 \mathrm{~cm}$ of sediment is possible in ostracods. However, the presence of the subsurface feeder $P$. femorata is likely to reduce the success of this strategy, by increasing disturbance and sediment disruption in deeper sediment layers. Thus, it seems likely that ostracods are forced to reduce their feeding activity on the added cyanobacteria when faced with high frequency amphipod and bivalve disturbance both at and below the surface. It is also possible that ostracods change their feeding strategy to consumer other unlabeled food sources when faced with high macrofauna interference. This would require ostracod species to actively avoid fresh organic matter from settling phytoplankton blooms while they forage in the sediments, which seems less plausible. However, our experimental design cannot distinguish these possibilities

The three ostracod species were differently affected by the increased interference caused by macrofauna, with C. neglecta showing the greatest reduction in isotope values when compared to the treatment without macrofauna (Fig. 1). Other studies have found C. neglecta to incorporate freshly deposited organic matter from phytoplankton blooms at much higher rates than the other two ostracods (Nascimento et al. 2008; Ólafsson et al. 1999). Modig et al. (2000) indicated that the different feeding ecologies of these three ostracod species might be connected to their life-history characteristics. In the Baltic Sea, $P$. fennica and $H$. sorbyana have a 2-year life cycle (Ankar and Elmgren 1976), while $C$. neglecta is able to reach the adult stage in 4 months (Savolainen and Valtonen 1983). The shorter generation time of $C$. neglecta probably requires it to feed and grow more quickly, and to use pulses of higher quality organic matter with greater efficiency. Nevertheless, in the multi-macrofaunal species treatments, this difference in assimilation of freshly deposited organic matter between $C$. neglecta, $H$. sorbyana and $P$. fennica was reduced, as incorporation of fresh bloom material by $C$. neglecta suffered the greatest decrease (Fig. 1). The more time an ostracod spends with its shells closed to avoid contact with macrofauna, the less time it will have available for feeding. It is, therefore, not unexpected that $C$. neglecta showed a greater reduction in incorporation. Our results suggest that outcomes of the effects of interference by larger competitors will depend on the life history traits and characteristics of the impacted species. 
Our results have implications for understanding mechanisms that underlie species coexistence in aquatic sediments. Few papers have studied both macrofaunal diversity and meiofauna abundance and distribution in systems below the photic zone with a taxonomic resolution that allows testing of meaningful hypotheses about their relationship. In one of these studies, Ankar and Elmgren (1976) present data on both macrofaunal and meiofaunal distributions at 35 stations sampled in a stratified random sampling design in the geographical area where we performed our experiment. Analyzing their data on the abundance and species composition of benthic communities below the photic zone $(\geq 15 \mathrm{~m})$ we found that both abundance and biomass of meiofauna are negatively correlated with macrofaunal biodiversity, measured as Shannon index (Fig. $4 ; r^{2}=0.27, P=0.0018$ for abundance; $r^{2}=0.12, P=0.034$ for biomass). Even though data from other geographical regions are needed, the negative correlation between macrofaunal diversity and meiofaunal abundance, and the increase in interference with higher species richness found in our study, indicate that interference competition with meiofauna by macrofauna is increased at greater macrofauna diversity.

As benthic communities living below the photic zone are critically dependent on pulsed inputs of settling organic matter for food (Graf 1992), most benthic deposit-feeders, like $C$. neglecta and to a lesser degree $P$. fennica and $H$. sorbyana, are sufficiently opportunistic in their diet to use an infrequently available resource. The ability of a consumer to increase consumption of a normally limiting resource when it becomes available in abundance has been shown to drive complex patterns of community dynamics in a number of ecological systems (Ostfeld and Keesing 2000; Yang et al. 2008). Our data show that an increase in species richness can intensify interference competition, and reduce the access of an impacted species to a limiting resource, potentially playing an important role in community dynamics. No effects of macrofaunal diversity on the abundance or biomass of ostracods were observed in our short study. However, the effect on the incorporation of freshly deposited cyanobacteria was clear. As incorporation of organic matter is the first step in somatic growth, it is a promising indicator in studies of factors controlling the secondary production of slow-growing species (Karlson et al. 2010).

Interference competition can be a decisive factor in community dynamics (Amarasekare 2002, 2003). Indeed, one of the most striking patterns in benthic communities is the decrease in abundance and biomass of benthic species with water depth, which is more rapid for macrofauna than for meiofauna (Rex et al. 2006; Thiel 1975). This transition to a meiofaunal dominated system in low energy habitats is also seen in the Baltic Sea with meiofaunal biomass exceeding that of macrofauna in the Bothnian Sea
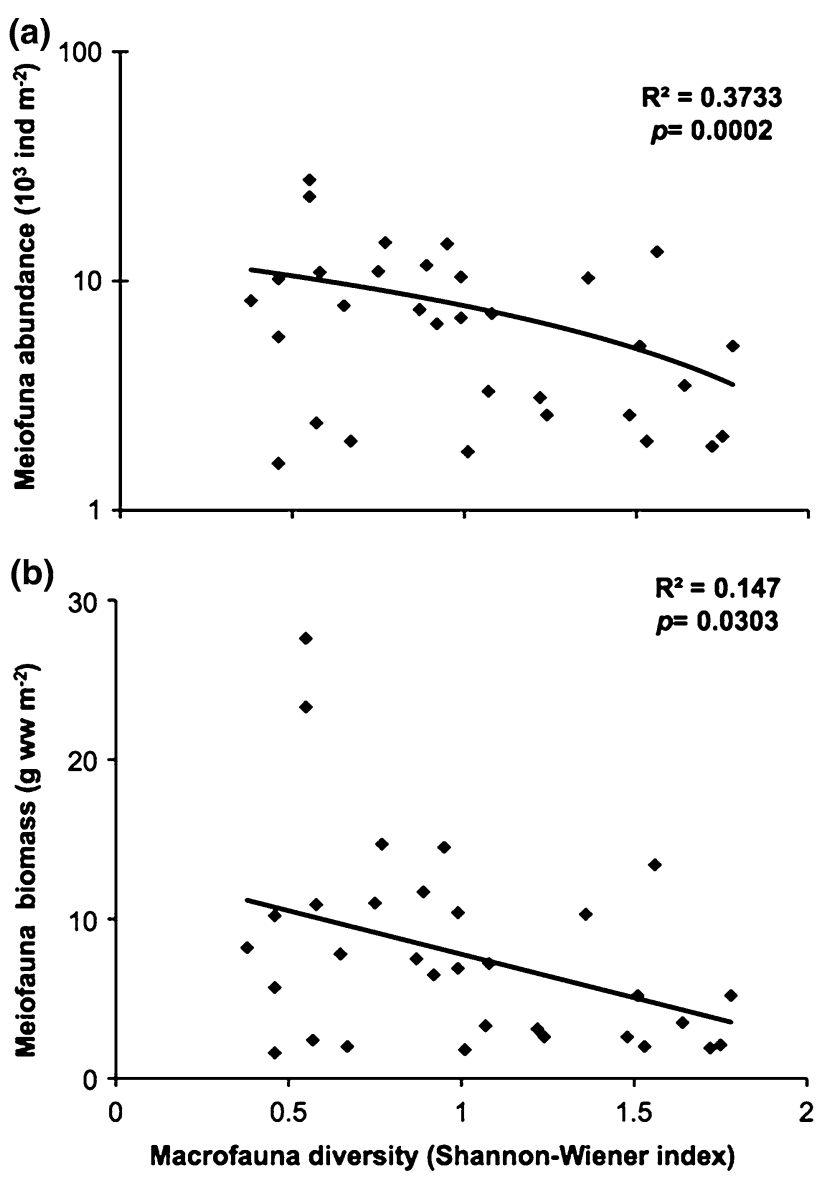

Fig. 4 Correlations between macrofauna diversity (Shannon-Wiener index) and a meiofauna abundance (log transformed), and $\mathbf{b}$ meiofauna biomass based on field data from the study area from Ankar and Elmgren (1976)

(Elmgren 1978). This transition is connected to lower food availability in this ecosystems, which do not provide enough energy to sustain high standing stocks of large organisms (Rex et al. 2006; Thiel 1975). As meiofauna have higher feeding efficiency than macrofauna (Elmgren 1978; Thiel 1975), their biomass and abundance decreases at a slower rate with depth. Our results suggest that another mechanism contributes to this global pattern of an increased proportion of smaller organisms with depth. We show that macrofauna interferes with the access of meiofauna to settled organic matter. With lower abundance and diversity of macrofauna in low energy systems, meiofauna may be released from interference competition and have better access to the food available, which may to some extent counterbalance the effect of lower food availability, thus contributing to the slower rate of decrease in meiofauna numbers and biomass and to the consequent decreasing size of metazoans with depth.

In conclusion, our study shows that interference competition from macrofauna can reduce incorporation of 
freshly deposited phytoplankton material by meiofaunal ostracods, and that this interference is aggravated when macrofauna species richness is increased, even at constant macrofauna biomass.

Acknowledgments Financial support was provided by the Swedish Research Councils Vetenskapsrådet and Formas to R.E. and by the Stockholm Marine Research Centre. F.J.A.N. was supported by a doctoral fellowship from Fundação de Ciência e Tecnologia, Portugal (POCI 210-BD 17844/2004). We thank the staff at the Askö Laboratory for technical and field assistance, $\mathrm{H}$. Höglander for help with taxonomic analysis of cyanobacterial samples, and E. Gorokhova and C. Bradshaw, C. Osenberg and two anonymous reviewers for helpful comments on the manuscript.

Open Access This article is distributed under the terms of the Creative Commons Attribution Noncommercial License which permits any noncommercial use, distribution, and reproduction in any medium, provided the original author(s) and source are credited.

\section{References}

Adler FR, Mosquera J (2000) Is space necessary? Interference competition and limits to biodiversity. Ecology 81:3226-3232

Aljetlawi AA, Leonardsson K (2002) Size-dependent competitive ability in a deposit-feeding amphipod, Monoporeia affinis. Oikos 97:31-44

Amarasekare P (2002) Interference competition and species coexistence. Proc R Soc Lond B 269:2541-2550

Amarasekare P (2003) Competitive coexistence in spatially structured environments: a synthesis. Ecol Lett 6:1109-1122

Ankar S, Elmgren R (1976) The benthic macro- and meiofauna of the Askö-Landsort area (northern Baltic proper). A stratified random sampling survey, vol 11. Contributions from the Askö Laboratory. Stockholm University

Austen MC, Widdicombe S, Villano-Pitacco N (1998) Effects of biological disturbance on diversity and structure of meiobenthic nematode communities. Mar Ecol Prog Ser 174:233-246

Basset A, Angelis DL (2007) Body size mediated coexistence of consumers competing for resources in space. Oikos 116: 1363-1377

Begon M, Harper J, Townsend C (1990) Ecology: individuals, populations, and communities. Blackwell, Oxford

Bianchi TS, Johansson B, Elmgren R (2000) Breakdown of phytoplankton pigments in Baltic sediments: effects of anoxia and loss of deposit-feeding macrofauna. J Exp Mar Biol Ecol 251: $161-183$

Blomqvist S, Lundgren L (1996) A benthic sled for sampling soft bottoms. Helgol Mar Res 50:453-456

Byrén L, Ejdung G, Elmgren R (2006) Uptake of sedimentary organic matter by the deposit-feeding Baltic amphipods Monoporeia affinis and Pontoporeia femorata. Mar Ecol Prog Ser 313:135-143

Chase JM et al (2002) The interaction between predation and competition: a review and synthesis. Ecol Lett 5:302-315

Connell JH (1983) On the prevalence and relative importance of interspecific competition-evidence from field experiments. Am Nat 122:661-696

De Roos AM, Persson L, McCauley E (2003) The influence of sizedependent life-history traits on the structure and dynamics of populations and communities. Ecol Lett 6:473-487

Elmgren R (1978) Structure and dynamics of Balthic benthos communities, with particular reference to the relationship between macro- and meiofauna. Kiel Meeresforsch Sonderh $4: 1-22$

Elmgren R, Hill C (1997) Ecosystem function at low biodiversitythe Baltic example. In: Ormond R, Gage J, Angel M (eds) Marine biodiversity, patterns and processes. Cambridge University Press, Cambridge, pp 319-336

Elmgren R et al (1984) Benthic macro- and meiofauna in the Gulf of Bothnia (Northern Baltic). Finn Mar Res 250:3-18

Erwin DH (2008) Macroevolution of ecosystem engineering, niche construction and diversity. Trends Ecol Evol 23:304-310

Giere O (2009) Meiobenthology: the microscopic motile fauna of aquatic sediments, 2nd edn. Springer, Berlin

Goedkoop W, Akerblom N, Demandt MH (2006) Trophic fractionation of carbon and nitrogen stable isotopes in Chironomus riparius reared on food of aquatic and terrestrial origin. Freshw Biol 51:878-886

Graf G (1992) Benthic-pelagic coupling-a Benthic view. Oceanogr Mar Biol 30:149-190

Heiskanen AS, Haapala J, Gundersen K (1998) Sedimentation and pelagic retention of particulate $\mathrm{C}, \mathrm{N}$ and $\mathrm{P}$ in the coastal northern Baltic Sea. Estuar Coast Shelf Sci 46:703-712

Hill C, Elmgren R (1987) Vertical distribution in the sediment in the cooccuring benthic amphipods Pontoporeia affinis and Pontoporeia femorata. Oikos 49:221-229

Karlson AML, Nascimento FJA, Näslund J, Elmgren R (2010) Higher diversity of deposit-feeding macrofauna enhances phytodetritus processing. Ecology 91:1414-1423

Larsson U, Hajdu S, Walve J, Elmgren R (2001) Baltic Sea nitrogen fixation estimated from the summer increase in upper mixed layer total nitrogen. Limnol Oceanogr 46:811-820

Lawton JH, Hassell MP (1981) Asymmetrical competition in insects. Nature 289:793-795

Lopez G, Elmgren R (1989) Feeding depths and organic absorption for the deposit-feeding benthic amphipods Pontoporeia affinis and Pontoporeia femorata. Limnol Oceanogr 34:982-991

Meyers MB, Fossing H, Powell EN (1987) Microdistribution of interstitial meiofauna, oxygen and sulfide gradients, and the tubes of macro-infauna. Mar Ecol Prog Ser 35:223-241

Meysman FJR, Middelburg JJ, Heip CHR (2006) Bioturbation: a fresh look at Darwin's last idea. Trends Ecol Evol 21:688-695

Modig H, van de Bund WJ, Olafsson E (2000) Uptake of phytodetritus by three ostracod species from the Baltic Sea: effects of amphipod disturbance and ostracod density. Mar Ecol Prog Ser 202:125-134

Nascimento FJA, Karlson AML, Elmgren R (2008) Settling blooms of filamentous cyanobacteria as food for meiofauna assemblages. Limnol Oceanogr 53:2636-2643

Nascimento FJA, Karlson AML, Näslund J, Gorokhova E (2009) Settling cyanobacterial blooms do not improve growth conditions for soft bottom meiofauna. J Exp Mar Biol Ecol 368: $138-146$

Ólafsson E, Modig H, van de Bund WJ (1999) Species specific uptake of radio-labelled phyto-detritus by benthic meiofauna from the Baltic Sea. Mar Ecol Prog Ser 177:63-72

Ólafsson E, Ullberg J, Arroyo NL (2005) The clam Macoma balthica prevents in situ growth of microalgal mats: implications for meiofaunal assemblages. Mar Ecol Prog Ser 298:179-188

Ostfeld RS, Keesing F (2000) Pulsed resources and community dynamics of consumers in terrestrial ecosystems. Trends Ecol Evol 15:232-237

Persson L (1985) Asymmetrical competition-are large animals competitively superior? Am Nat 126:261-266

Post DM, Layman CA, Arrington DA, Takimoto G, Quattrochi J, Montana CG (2007) Getting to the fat of the matter: models, methods and assumptions for dealing with lipids in stable isotope analyses. Oecologia 152:179-189 
Rex MA et al (2006) Global bathymetric patterns of standing stock and body size in the deep-sea benthos. Mar Ecol Prog Ser 317:1-8

Savolainen I, Valtonen T (1983) Ostracods of the north-eastern Bothnian Bay and population dynamics of the principal species. Aquilo Ser Zool 22:69-76

Schoener TW (1983) Field experiments on interspecific competition. Am Nat 122:240-285

Thiel H (1975) The size structure of the deep-sea benthos. Int Rev Ges Hydrobiol 60:575-606

Tita G, Desrosiers G, Vincx M, Nozais C (2000) Predation and sediment disturbance effects of the intertidal polychaete Nereis virens (Sars) on associated meiofaunal assemblages. J Exp Mar Biol Ecol 243:261-282

Valeix M, Chamaille-Jammes S, Fritz H (2007) Interference competition and temporal niche shifts: elephants and herbivore communities at waterholes. Oecologia 153:739-748

Walsby AE (1975) Gas vesicles. Annu Rev Plant Phys 26:427-439

Wilson WH (1990) Competition and predation in marine softsediment communities. Annu Rev Ecol Syst 21:221-241

Yang LH, Bastow JL, Spence KO, Wright AN (2008) What can we learn from resource pulses? Ecology 89:621-634 